\title{
Enriching indigenous knowledge scholarship via collaborative methodologies: beyond the high tide's few hours
}

\author{
Julie Velasquez Runk ${ }^{1,2}$
}

\begin{abstract}
Over the last $20 \mathrm{yr}$, anthropologists have demonstrated an increasing interest in collaborative and decolonizing methodologies. Despite this trend, there are relatively few works that illustrate how research collaborations have affected scholarship. In this paper, I demonstrate how the use of collaborative methodologies has allowed me to better understand indigenous knowledge of Wounaan in eastern Panama. In particular, I examine the use of three different aspects of collaboration-codesigning research, coanalyzing results, and coauthorship — with local experts, leaders, and communities over $17 \mathrm{yr}$ and how they have enriched my research on ethnoecology, political ecology, and linguistic anthropology. I also address how this solitary reflection has underscored the importance of process and multivocality in collaboration. The results illustrate how collaborative methodologies may engage different aspects of indigenous practice than participant observation, and how both methods mutually reinforce enhanced understanding of indigenous knowledge and the production of science.
\end{abstract}

Key Words: collaboration; Emberá; indigenous knowledge; Panama; science and technology studies; Wounaan

\section{INTRODUCTION}

The study of indigenous knowledge rose in prominence as a response to modernity's deskilling image of indigenous communities and the resultant effects upon them (Dove 2006). In the ensuing years, there has been greater acknowledgment that indigenous knowledge is gendered, political, situated, practiced, enskilled, and performed, and that it is variable over time and space (Ellen et al. 2000, Stepp et al. 2002, Battiste 2008, Zent 2009, Johnson and Hunn 2010, Andrae-Marobela et al. 2012). Over time, researchers have also recognized the processual and hybrid nature of indigenous knowledge, that it is part of "creative synthesis of local and global, insider and outsider, traditional and modern, forms of knowledge" (Zent 2009: 44). As a result of these changes, in part, researchers and communities studying indigenous knowledge have generally expanded their toolkit of mixed methodologies.

One such method is collaborative research: ideally work that is planned, carried out, analyzed, and written up together. By more closely collaborating with communities and multiple community members, collaborative research facilitates studies that are targeted to local needs, and its proponents often argue, are more ethnographically engaged with local realities, more readable, and potentially decolonizing (Lassiter 2005, Rappaport 2005, Gow 2008, Breunlin and Regis 2009). Like the approaches known as indigenous or decolonizing methodologies (Smith 2002, Denzin and Lincoln 2008), collaborative research also considers that local participants must conduct, own, and benefit from research that is done on, for, or with them. Collaboration helps dismantle what Agrawal (1995) has called the divide between indigenous and scientific knowledge by acknowledging multiple visions, agendas, and expectations (Lassiter 2005). Similar to TallBear's (2014:1) inquiry in concert, collaboration seeks out and articulates "overlapping respective intellectual, ethical, and institution building projects."

To be clear, participation differs from collaboration. The hopeful integration of indigenous knowledge into conservation and development, often couched as participation, was done with the intent of making both more successful (Nazarea 1999, Sillitoe et al. 2002). Although there is a broad spectrum of participatory research, within the literature on indigenous knowledge, participation has been roundly critiqued for, at best, providing a veneer of local input to research and, at worst, integrating simplified notions of indigenous knowledge that serve to reinforce the power of the technical, nonindigenous elite (Agrawal 1995, Nadasdy 1999, Cooke and Kothari 2001, Yarrow 2008).

There have been markedly few studies that have examined how collaborations among scientists and local experts have affected scholarship (Thomas 2009, Andrae-Marobela et al. 2012, Echeverri and Román-Jitdutjaaño 2013), which is especially notable given the growth of science and technology studies' focus on the politics of knowledge. This differs from the growing literature that describes the collaborative method itself (e.g., Butler 2004, Shackeroff and Campbell 2007, Allen et al. 2009, Lowe et al. 2009, Lyver et al. 2009, Mullins 2011, McGinty 2012). This relative lacuna is all the more striking given that the literatures on both indigenous knowledge and collaboration result from similar epistemological engagement on agency and power. For example, Zent (2009: 44) has noted "the hybrid nature of indigenous knowledge is thought to constitute a potential source of agency and empowerment for marginalized peoples." That is, indigenous knowledge research explicitly incorporates the insights of local resource holders and users, rather than that of the researcher alone, and by doing so, shifts some power from the hands of the researcher. Similarly, Cook (2009: 113) has observed "power (however defined) and its relocation is the focal concern of collaborative ethnography or anthropology."

In this article, I demonstrate how the use of collaborative methodologies with indigenous Wounaan over a period of $17 \mathrm{yr}$ has allowed me to gain new perspectives on indigenous knowledge in eastern Panama. Specifically, I address findings from codesigning research, coanalyzing results, and coauthoring with local experts, authorities, and communities. Here, I reflexively, and a bit uncomfortably, highlight my understandings of these collaborations and what I learned about indigenous knowledge 
from them. My discomfort in doing so also allows me to discuss my ironic position of solitary reflection and underscores the importance of multivocality and process in collaboration. I conclude that conceptualizing indigenous knowledge as those forms of knowledge held by and practiced by indigenous peoples requires research collaboration, and this need is magnified in the recognition of research as a recursive process. As such, the conceptualization of indigenous knowledge and the collaborative methodological approach to it are mutually constitutive. These results relate to a growing literature on coproduction in collaboration (Lassiter 2005, Rappaport 2005, Field and Fox 2007, Field 2008, Gow 2008, Jones and Jenkins 2008, Laborde 2013).

\section{RESEARCH SITE}

Eastern Panama is well known as a region of conservation interest as part of the diverse Darién/Chocó biogeographic region (Dinerstein et al. 1995, Brooks et al. 2002). It is the most forested area of the country and also known as a place where oceans, rivers, and land intermingle in a relatively small place. Since the early 1990 s, sporadic violence has occurred in the far eastern region, attributed to spillover from the Colombian civil conflict. Indigenous Emberá, Wounaan, and Guna, as well as black and mestizo populations make up the region's inhabitants.

Previously grouped together and referred to as "Chocó," Wounaan and Emberá are two groups of Panama and Colombia. According to the last census, there are 31,284 Emberá and 7,279 Wounaan in Panama (Dirección de Estadística y Censo 2012). Both groups are largely swidden agriculturalists, hunters and gatherers, artisans, and wage laborers. Historically, the groups are egalitarian. In the 1950s, Emberá and Wounaan began forming villages (Herlihy 1986). In the following decade, the government promoted Emberá and Wounaan village formation, as well as the adoption of the hierarchical leadership body (modified from that of Guna), known as a congress (ibid.). In 1999, Wounaan split off from Emberá and created their own congress and foundation, respectively, the National Congress of Wounaan People (Congreso Nacional del Pueblo Wounaan (CNPW)) and the Foundation for the Development of Wounaan People (Fundación para el Desarrollo del Pueblo Wounaan (FUNDEPW)). Yet, some Wounaan, particularly in their reserve lands legalized in 1983 (known as the Comarca Emberá-Wounaan), maintain allegiances to the Emberá-Wounaan congresses.

Emberá and Wounaan still tend to be native speakers of their language, Emberá b'edea and Wounaan meu, which comprise the Chocó language family. Almost all are also Spanish speakers. Both groups remain cultures dominated by oral traditions; although most Emberá and Wounaan are literate, reading texts is not prevalent.

\section{METHODS}

This paper is about research carried out in eastern Panama from late 1996 to the present, yet collaborations had been fundamental to previous research and employment. In undergraduate and Master's research (in Costa Rica and Ecuador, respectively), I had negotiated my interests with those of local NGOs and community members, and provided my results, as they requested, in management manuals. For international NGOs, I had worked with teams of supervisors and colleagues to develop programmatic plans and proposals, manage grants, write reports and curricula, and hold workshops. Here, I detail research during three distinct projects in Panama, each using mixed methods and different levels of collaboration. I refer to each project chronologically.

From the late 1990 s to early 2000 s, I worked as a conservation and development practitioner with the Cativo and Non-Timber Forest Product (NTFP) Project with campesino and indigenous communities of Darién, known as Proyecto Cativales. This was one of five, large, million- or multimillion-dollar conservation and development projects in the region at that time. Initiated by international researchers via the Smithsonian Tropical Research Institute (STRI), the project subsequently was integrated with Panama's governmental environmental agency, and then negotiated with communities for work on black, mestizo, and indigenous lands. I worked as the scientific coordinator of nontimber forest products, studying the ecology and socioeconomics of Wounaan and Emberá commercial basketry and carvings. I lived in rural eastern Panama during $2 \frac{1}{2} \mathrm{yr}$ of intense learning, and rigorous and enjoyable fieldwork, and consulted for $2 \frac{1}{2}$ yr more. I worked with two Wounaan research technicians in sequence (Floriselda Peña Conquista and Pinel Mepaquito Teucama), an Emberá boat driver/cook (Sergio Achito Mecha), and an ecological field crew of two to three local black or indigenous residents (who varied by site locale, Eleuterio Achito Mecha, Evaristo Achito Mecha, Silco Achito Mecha, Alonso Dogirama, Camillo Grillo, and Nestor Marín). We typically worked in Spanish, but also in Wounaan meu and Emberá b'edea. Methods for that research included forest vegetation plots to study growth and yield, geographic information system (GIS) maps of resources, semistructured interviews on art production and livelihoods, and participant observation.

Proyecto Cativales was designed without local input, and I pushed for more collaboration with local indigenous leaders, residents, and artisans. Yet, there was governmental reticence to concede expertise to the two U.S. scientific coordinators, which I attribute to tensions with the United States of America as a colonial presence in Panama. Changes were difficult and time consuming, requiring work through multiple administrations in the distant capital. In addition, the government had not yet recognized the organization or lands of Emberá and Wounaan villages living outside their Comarca, but did eventually sign written agreements with them (a local norm that dates to the colonial era with Guna (Gallup-Díaz 2001). I refrained from working in indigenous lands until the project negotiated agreements, struggled to hire indigenous research technicians for their local and language expertise, and succeeded in obtaining project permission to spend more than just the high tide's few hours to work with indigenous villages. Those experiences deeply shaped my commitment to working collaboratively with landholders and resource users.

From 2002 to 2004, I studied the cultural and political ecology of Wounaan forest use. This was my dissertation research, during which time I lived $2 \mathrm{yr}$ in two Wounaan villages, and another $1 / 2$ $\mathrm{yr}$ between them and the Panama City Wounaan community. By the time I began this research, I was familiar with the area, Wounaan culture, and the research agreement norm. Although I did not know many of the leaders, I later learned that they often 
had heard of me, typically as a North American woman who liked to hike around rural eastern Panama with a pack on her back. Whereas tales had me scaling mountains I had never climbed, these stories granted me privilege as someone who could do hard labor rather than simply office work. Both CNPW and FUNDEPW were encouraging and supportive, and I began planning research (as described below). I worked in each village with one assistant researcher (Gervacio Ortíz Negria, Wilio Quintero Quiróz, and Cristobalino Quiróz Ismare) and ecological teams of three to four additional people (Leonardo Peña Conquista, Gelo Mejía Peña, Freicer Peña Ismare, Yani Cheucarama Chiripua, Mayolo Obispo Donisabe, Wilio Durán Conquista, Francisco Cheucarma Conquista, and Ballarino Cheucarama Membora), all nominated and elected by residents. Research methods were vegetation plots of a chronosequence of forest uses, participatory mapping of village lands, vegetation types, and cultural sites using GIS, satellite image analyses, semistructured interviews of household history and forest use, participant observation, community history workshops, and recordings of oral traditions, as well as semistructured interviews with conservation and development practitioners and scientists.

From 2010 to 2014, I have been leading a collaborative project documenting the Wounaan language with the University of Georgia, University of Arizona, and FUNDEPW. I coordinated initial planning with a U.S. anthropologist and a linguist who supported collaborative work (Elizabeth Lapovsky Kennedy and Ronald Binder, respectively), and the CNPW and FUNDEPW leaders. As I discuss more below, this resulted in project and proposal planning with national Wounaan leaders, esteemed cultural experts, and a storyteller or leader from all Wounaan villages. The project is composed of a linguist, an anthropologist, and a joint linguistics and anthropology graduate student (Binder, Kennedy, and Bryan James Gordon, respectively) together with a team of Wounaan: an appointed leader, a team of five language experts, and a half-time administrator (Chenier Carpio Opua, Toño Peña Conquista, Chindío Peña Ismare, Tonny Membora Peña, Doris Cheucarama Membache, Chivio Membora Peña, and Roy Teucama Barrigón, respectively). Research goals are to archive, transcribe, and translate $60 \mathrm{yr}$ of recordings of Wounaan oral traditions and to linguistically analyze those materials, including the development of a dictionary and a grammatical sketch. In 2012, I took a linguistics class with our Wounaan team at the American Indian Language Development Institute (AILDI).

Importantly, it is only during this last project that cell phones and email have become commonplace among city- residing and many rural Wounaan. In prior years, communication with Wounaan required my physical presence, as Wounaan had virtually no mailing addresses, few land lines, and scant email accounts.

\section{RESULTS}

I address results in terms of three different collaborative research phases, rather than chronologically: codesigning research, coanalyzing research, and coauthoring research.

\section{Codesigning research}

I initiated cultural and political ecology research collaboratively. During Proyecto Cativales, Wounaan colleagues encouraged me to work only with their group: they had renown as master artisans, had conserved much of their language, and yet there was markedly little ethnographic information about them. I knew that I would need to meet with Wounaan leaders to develop research and an agreement; however, rather than the pro forma agreements that I knew as a practitioner, I wanted to develop something of a decolonizing agreement that explicitly addressed interests and commitments of all parties. I heard about the work by Sarah Laird on ethical research agreements (later published as Laird and Noejovich 2002) and contacted her for suggestions. I decided to spend the summer studying Wounaan meu and developing research. This was a welcome contrast to previous work in Panama, where multiple forest and village sites required constant moving around: I was excited about slowly and cautiously putting my efforts into learning Wounaan meu, collaboratively outlining research, and codifying commitments in an agreement.

I initially outlined research with national Wounaan leaders. For a summer, I met regularly with five to ten Wounaan leaders and community members in open, enjoyable conversations about how to address our interests. I explained my research interests as trying to understand how Wounaan use their lands, especially forests, how that changed over time, and how that related to biodiverse Darién and its conservation. Leaders saw research as a means to document their culture and history, as they were frequently confused with the more numerous Emberá. Additionally, Wounaan were embroiled in land rights conflicts that privileged that larger group: they encouraged my interest. Wounaan respected the power of writing, and supported my dissertation as "your book."

Wounaan leaders and I negotiated aspects for exclusion and inclusion in the research. As part of this process, I oriented Wounaan to key research resources and sites in Panama City, including discussing GIS maps and satellite images, and touring the STRI library and herbarium. In accordance with a longestablished ban, Wounaan prohibited me from studying medicinal and luck plants. I quickly assented: I was familiar with the ban and had studied ethnobotany during a period of medicinal plant biopiracy scandals. Instead, leaders asked me to train them in western botany and botanical methods so that they might undertake future study of medicinal plants. They also asked that I map each research village's collective land holdings, as cartography was increasingly important for planning and as a tool to seek land rights. We committed to raising college scholarship funds, and encouraged assistant researchers to use part of the studies for their own college theses (which, regrettably, never happened). I proposed a 10\% overhead fee to CNPW and FUNDEPW from my funding when possible: this allowed our continued conversation, given that the organizations frequently lacked bus fare. We discussed many other details, including which communities were safe for research because of violence from the Colombian conflict; that communities would nominate assistant researchers and set pay rates; and we established guidelines for results presentation and article coauthorship. The STRI lawyer (Natacha Chandler) helped me to edit the draft into Panamanian legal style, the same that had been adopted by the CNPW. By the end of the summer, we had a draft agreement for which I needed to raise funding.

The next steps were Wounaan village and national approval. The research was well timed, as its approximate initiation coincided 
with the Wounaan National Congress, a 3-day meeting of all Wounaan villages held every 2 yr. There, leaders facilitate discussion of salient cultural and political issues: I could plan and discuss research at national and village levels for final approval at the Congress. With the draft agreement in hand, the CNPW Chief, FUNDEPW President, and I traveled to the two proposed research villages. I invited a former research technician (Pinel Mepaquito Teucama) from Proyecto Cativales as a SpanishWounaan meu interpreter so that the Chief and President would not compromise their independent leadership roles by aiding me. These were collegial trips, characterized by teasing, dry season sun, and an unexpected hike when transportation failed. In each village, we held a local congress, a community meeting, and discussed the proposed research with village leaders and residents. The questions asked at this level were mirrored in the subsequent discussion at the Wounaan National Congress a month later: a request not to study medicinal plants, and questions about who would work with me and logistics, such as where I would live and when I would start. We left each village copies of the draft research agreement (in Spanish) to consider and discuss over the following weeks. On the final day of the 1,300-person Wounaan National Congress, the FUNDEPW President presented the research under the "agreements" agenda item. The President asked the leaders of the potential host villages about their community's opinions, and each relayed their support. Indigenous authorities then opened up the floor for discussion by the plenary, and leaders answered the above questions with reference to the agreement text. At the end of the discussion, a voice vote confirmed the approval of the research agreement, with no dissenting votes. That evening, the Wounaan Chief, President of the Wounaan Foundation, elected leaders of each research village, and I signed the agreement, which was documented with a photo. I returned to Panama City to pick up my belongings and began research 2 d later.

The comments by community members and requests made by Wounaan leaders in drafting, negotiating, and carrying out research under an agreement facilitated my own learning. In many ways, this was because we embraced a processual approach, responding to each other's concerns and needs. For example, Wounaan's repeated concern that I might study medicinal plants made it obvious that I should avoid and be cautious about the topic. It also heightened the need for teaching western botany early on. A Panamanian botanist (José Deago) who worked at the Smithsonian offered to teach a botanical workshop, which allowed Wounaan assistants and leaders to comprehend western botany and its plant characters. Scientists might cringe that I was muddying Wounaan taxonomy, however, I think Wounaan and I tacitly understood that we were engaging in reciprocal exchange of botanical information. The botanical training gave me early entry to less common aspects of oral traditions. For example, when discussing the unusual flowering of figs, Wounaan explained how those who see fig flowers, which they reasoned must bloom at night, will capture tremendous wealth from them. That workshop also gave me knowledge about spiritual uses of plants. For example, during the class walk through Panama City's Parque Metropolitano, several Wounaan began to comment rapidly about a plant in the Psychotria genus. This catalyzed a conversation about how some plants like this Psychotria, a monoamine oxidase (MAO) inhibitor, when mixed with
Banisteriopsis spp. allow shaman to visualize the spirit world.

Through mapping, I gained a better understanding of community landscapes. In particular, participatory mapping forced me to visit downriver littoral areas, where I documented use of distinct resources. Hiking to the farther reaches of community lands in order to map aided my understanding of Wounaan cosmology and the differential inhabitation of malevolent spirits in such less domesticated spaces. As I increasingly understood Wounaan cosmology, I had a growing appreciation for the limitations of mapping, of reducing the complexities of a dynamic landscape and invisible spiritscape to a static map. In one village, I was asked to join men from most of the households in a junta, a work party, to map as they used machetes to cut the trocha, a wide boundary swath. This participatory mapping gave most of the community's households an opportunity to witness me in the field and to understand the role of a GPS unit in the mapping process. I learned about the spatiality of community lands, about boundary areas as loci of conflict from outsider encroachment and illegal logging. For Wounaan, the mapping was instrumental for subsequent land rights efforts: 5 yr later, village leaders authorized me to give government officials the GPS boundary data. This aided one of the villages in obtaining collective title in 2012, one of only two such titles in the country (the other village's land petition still is pending).

In 2007, I met with national Wounaan authorities and asked what research they most wanted. Their highest priority was obtaining legal rights to collectively held Wounaan land. However, that was politically charged work, difficult for an individual, and I recommended that they seek continued funding with NGOs already working with them on it. Leaders also expressed interest in language efforts, particularly for the education of their children. Four of us extra-local linguists or anthropologists (including the late Jacob Loewen) collectively had over $60 \mathrm{yr}$ of audio recordings of Wounaan myths and legends in their language. Working with the two remaining scientists (Elizabeth Lapovsky Kennedy and Ronald Binder) and Wounaan, we decided to repatriate the recordings and archive them for permanence, as well as use them as source material for linguistic study. In 2008, I coordinated a meeting of scientists, FUNDEPW, CNPW, and village leaders and storytellers to plan a grant proposal. During our meeting, we discussed different aspects of indigenous knowledge: the intellectual property of stories known by many, but now narrated by few; whether the names of storytellers could be used as traditionally Wounaan do not mention names of the deceased, what to do with bawdy comments made in the recordings; and whether and how stories for which we had multiple versions by different narrators would be registered with Panama's Indigenous Intellectual Property Rights Law (Law 20 of 2000).

Two years later, at the initiation of our NSF grant, we held another meeting with Wounaan village and national leaders to collaboratively finalize research plans. Our 2010 plans were particularly difficult, as coinvestigator Kennedy and I received final word of the grant award in early May, finished our semesters, and were in Panama by early July. Within a relatively quick period, I ordered and transported equipment, made accommodations for U.S. collaborators, underwent institutional review, organized invitations and logistics for a planning meeting, arranged subsequent linguistics training, and coordinated labor contracts 
to initiate the project. I will spare the details here, as the FUNDEPW principal investigator Chenier Carpio Opua and I are writing about that collaborative process and its challenges. Suffice it to say that, together, we revised the research plans in 2011, when FUNDEPW members elected new leaders and the government passed a new law on Bilingual Intercultural Education (Law 88 of 2010). We rebudgeted the entire grant, removed much funding from the U.S. graduate student, and hired two new positions in Panama: a new language expert to integrate the stories into curricula and coordinate with the Ministry of Education and a part-time administrator to manage the project locally through FUNDEPW. This required additional trips to and time in Panama, but created a stronger grant more relevant to Wounaan and more engaged with recent policy. It also improved communication and trust.

\section{Coanalyzing results with local experts, communities, and authorities}

In the first project on Emberá and Wounaan artisanal nontimber resources, coanalyzing was part of a long process of working with indigenous colleagues who guided me as to what was and was not appropriate to study. For example, during research, they, leaders, and community members made it clear that some specialized knowledge, such as shamanic and botanical knowledge, is not public and, in fact, is something for which Wounaan long have paid. In the late 1990s, Emberá and Wounaan congresses typically began with a lengthy discussion of the need to protect indigenous knowledge and intellectual property rights, gýven the history of Spanish and Panamanian thefts of land, gold, and cures for malaria. As a result, there was tremendous awareness about the potential of outsiders to steal indigenous knowledge and resources. Given these concerns, I was quite careful about addressing only ethnobotanical knowledge that Emberá and Wounaan agreed to. Emberá and Wounaan made no restrictions on me, but when I published an article on basketry, I elected not to give scientific names of dye plants that were not already published (Velásquez Runk 2001). Although I thought of this article as a means to document and promote Emberá and Wounaan art, something that indigenous leaders, artisans, and project team members overwhelmingly supported, I only was able to dedicate time to data analysis after I had returned to the United States. Soon after publishing it, I thought of the basketry article as a lost opportunity to coanalyze and coauthor research.

With the cultural and political ecology research, I worked with three sets of local Wounaan experts who helped analyze data: assistant researchers, community members and national leaders, and interested others. I cannot overstate how committed and generous the assistant researchers were on an everyday basis. It was through daily conversation hiking to field plots or chatting about news that I became skilled in the landscape, gaining broad and material understanding of Wounaan resources, cosmology, and history. Much of this bears the hallmark of participant observation, of learning by doing, but I also think that collaboration instilled open, fun, and adaptive fieldwork. I recall sitting in my house with a chalkboard, all of us with cups of coffee, as I marked up the board with the ecological assistants' observations on the merits and pitfalls of potential plot sites. With the ecological team, our debriefings of a day's work as we pressed plants also became a time when community members wandered by to see what we found, offered their observations, and together we discussed our results. It often was during these late afternoons that community members observed what I needed, and recognizing that I lacked land, husband, and canoe, stepped in to provide new logs for my hearth, fish for my meals, and the like.

Community members had a particular role discussing initial results on ethnohistory. Interviewing heads of households, via a $90 \%$ random sample of each village stratified by kin grouporiented neighborhoods, had demonstrated conflicting versions of village history. Leaders of both villages wanted to clarify and formally document their history by resolving dates, and so I convened community history workshops. Over several hours, assistant researchers and I facilitated a discussion of prominent events that had been named in household interviews, allowing us to place them in a historical chronology (a bit tricky given the absence of calendars in earlier eras). Through this process, it was clear that villagers privileged natural disasters, illness, land conflicts, and community developments (e.g., the arrival of the first government schoolteacher) as critical components of history. Although the linearity of these chronologies struck me as quite western, it was what leaders requested, and was countered by the culturally relevant historical events named by residents.

Wounaan leaders and interested others, typically Wounaan professionals, reviewed, or perhaps better said, analyzed two draft dissertation chapters in Panama City. I had discussed research with Wounaan throughout, including presenting at local, regional, and national congresses when I lived in Panama. At those points, though, I did not have my thoughts very well ordered for comment. Writing also is analyzing, and brings to bear colonial traditions of writing about others: I was uncomfortable writing about Wounaan without their analysis and review. To me, this was particularly pronounced when writing about culture, rather than, say, vegetation plots. I met with two elders to address a cosmology chapter. I verbally reviewed the chapter, and together, we discussed it; both men made clarifications or corrections on vegetation categories, spelling of shamanic rituals, or my interpretation of myths. I met with a larger group of leaders and interested others to discuss ethnohistory. The assembled people provided vignettes and examples of the how and why of ethnohistory, such as what Wounaan consider a mass poisoning that motivated much migration from Colombia to Panama or in what ways they regard Emberá as different from them. This latter issue was of particular Wounaan import, holding the potential to correct the historical error of a singular, often hyphenated, ethnic group (Emberá-Wounaan). It was during this meeting that leaders asked me not to attribute comments to particular Wounaan but rather state "one Woun said." This suggestion underscored the importance of egalitarianism for Wounaan, and what I interpret as a desire to present unified cultural beliefs. This Wounaan preference runs counter to current anthropological thought to describe heterogeneity within cultures: reviewers often critique my writing because I continue to respect Wounaan's decision to avoid attribution of comments to named individuals.

In the language project, five Wounaan experts have worked full time transcribing and translating their stories, as well as integrating those stories into bilingual intercultural curricula. Our ongoing review of results with those language experts has meant a continual discussion amongst them and a dialog with us about how to transcribe concepts that are difficult to translate. For 
instance, one advanced language expert brought up a compelling example with the Wounaan meu word "p'ich." For Wounaan, it is onomatopoeic for the quiet sound of a jaguar flicking its tail. But combined with the helper verb "k'am," the words can also be used as a verb to fight in prolonged hand-to-hand combat. For Wounaan, it is such ideophones, words that represent sensations or sensory perceptions, especially such onomatopoeic ones, that are particularly onerous translations. In addition, the comparative study of linguistics as part of language documentation also has been insightful. During linguistics class at AILDI, diagramming Wounaan meu with other indigenous language speakers helped us draw conclusions about language and indigenous knowledge. For example, it was during a discussion of a diagrammed sentence that we decided to study the system of pluralizing suffixes in Wounaan meu and clarify them for younger native speakers.

\section{Coauthorship}

Coauthorship with indigenous colleagues was something of an organic outgrowth of collaborative research. It was acknowledging my regret about sole authoring (described above) and my failure to support the training of Wounaan in scholarship that led to my next publication. I worked in Panama with both Proyecto Cativales Wounaan research technicians to develop a research presentation on temporal and spatial considerations of NTFP use, copresent it, and then copublish it (Velásquez Runk et al. 2004). Coauthorship helped me bridge the theoretical and the practical in writing up research. In that paper, we concluded with indigenous knowledge in the current political context: we noted that NTFP harvest provided valuable income for many artisans, but that for Wounaan, securing legal rights to land was foundational to resource access and management.

In the cultural and political ecology research, coauthorship varied. First, a dissertation, as university rules dictated, is individually authored. However, I discussed this with Wounaan leaders early on, and while they referred to "my book" and made suggestions for it, we also incorporated article coauthorship in the research agreement. I acknowledged the research's collaborative nature by including significant contributors beneath each chapter's title. For articles, I sole-authored one in which I used Deleuze and Guattari's (1987) idea of rhizomes, a new theoretical approach that I had not discussed with Wounaan colleagues (Velásquez Runk 2009). And I coauthored research that I extensively and iteratively discussed with local assistant researchers, even though we did not have the communication media to cowrite. For example, a study of Wounaan livelihoods was coauthored with the main assistant researchers. who had worked intensively on household interviews and a census, and had repeatedly discussed results (Velásquez Runk et al. 2007). Reviewing those data, assistant researchers were reflexive of how livelihood opportunities and cultural preferences related to their own lives. I coauthored another article with ecological field teams on land-cover differences between remotely sensed satellite imagery and vegetation plots (Velásquez Runk et al. 2010). Local understandings of landscape were crucial for research design and placing results within local environmental and historical contexts. It was through the process of returning and discussing satellite image-derived maps that the power of remote sensing in making landscapes legible and illegible became clearer to me.
In the ongoing language documentation research, we are focusing on dialogic editing, that is, writing and editing together. I am grateful to Les Field for the suggestion: he pressed me on this point in a 2007 presentation. The language team, including U.S. and Wounaan researchers, initially outlined the language experts' presentation for AILDI. Then, the language experts developed, we all commented, and they edited and presented. Through those presentations, I acknowledged that decreasing rural dependence fostered nostalgia for material culture and knowledge in sharp decline, such as men's loincloths and manual sugar cane presses. Later, when I discussed these waning traditions, one Woun included a political-economic lament: that the increase in drug trafficking by Colombian "unknowns" made it unlikely that they might ever return to rural dependence. It only has been in the last year, as we have evaluated the project and planned future research, that we have compiled enough experience among our team to discuss in depth Wounaan meu sociolinguistics. In September 2013, we copresented three talks to the Panamanian Anthropology Congress: on the collaborative process, terms difficult to translate from Wounaan meu to Spanish, and changes in sociolinguistic context of Wounaan storytelling. Coauthoring presentations, rather than written work, better coincides with Wounaan oral traditions. It also allows skill building more in line with current Wounaan needs; how to tell a story in the context of a short talk and how to work with images and audio in presentation software. Yet, witnessing the impermanence of presentations and with a proposal reviewer's encouragement, the language team has increasingly appreciated the scientific standard of written publication to assert and disseminate research findings, especially to local audiences.

\section{DISCUSSION}

Each of these projects was about local cultural understandings, but none was explicitly an indigenous knowledge project. Writing up these research experiences and recasting them in terms of indigenous knowledge has made me uncomfortable, because it seemed, as Cruikshank (1998) has stated, to reify meanings to abstract concepts. That is, reconsidering these projects in terms of indigenous knowledge seemed to turn an outsider's gaze upon them, but also to remove them from larger cultural-politicalhistoric contexts: it essentializes by placing them against an implied opposition to nonindigenous knowledge. As Wholing (2009) has explained, this can diminish and ossify dynamic living practice. Yet, this perspective on indigenous knowledge stems from its earlier history in the ethnoscience era. I responded to the original call for papers (for the American Anthropological Association panel on which this special feature is based) because of the organizers' embrace of a heterogeneous, hybrid, practicebased indigenous knowledge. This, then, has been my own challenge: to address more recent thinking on processual indigenous knowledge. Here, by acknowledging my incipient to developed collaborations, I have attempted to show how method has affected scholarship: how the practice of multiple, different collaborations over a number of years have facilitated continuous, recursive, and hybrid notions of knowledge.

I also have been unsettled by the sole use of my voice as author of this manuscript, rather than those of Emberá, Wounaan, and other colleagues. Doing so misconstrues this work as less processual, paradoxically magnifying the decontextualization of indigenous knowledge by eliminating direct indigenous 
perspectives, but also those of other scholars, activists, and practitioners. I increasingly used collaborative methodologies over the years to mitigate such colonial and homogeneous potentials and, in turn, to minimize my voice. In this manuscript, then, I am sole author simply because these are my own perspectives, a situation, ironically, I sought to moderate by methodology. These circumstances highlight not only the continued restrictive positioning of indigenous knowledge, but also the potential insights of multivocality in collaborative methods. They also underscore the politics of knowledge in both.

Collaboration is particularly powerful in indigenous knowledge research because it is tacit acknowledgement of networked reciprocity and sociality, which have foundational roles in many cultures. Paige West's (2006) ethnographic study of a conservation and development project in Papua New Guinea illustrated the disappointment when reciprocity was overlooked. She showed how conservation and development practitioners and Gimi peoples had different goals for conservation work, with Gimi's expectations for benefits such as medicines and technologies not met when they granted land, labor, food, and friendship to the practitioners. In the research I discussed here, agreements codified reciprocity and demonstrated a willingness to participate in exchange as part of research process. Reciprocity also is about sociality, about building relationships and social networks, and I concur with Tallbear's (2014) admonition to think creatively about the research process as relationship building to break down the researcher-researched binary. Above, I attempted to illustrate the building of those research and social networks over time. I note here that these relationships also organically extend outside of the more formalized research environment, and I have learned much from friendships. For example, it was while helping a friend take home a young nanny to her rural village that I closely witnessed the alarming, acute manifestations of illness by malevolent spirits, how it is treated, and how those spirits move across the landscape. As that implies, relationships thus extend through the cosmos of human and nonhuman beings (Velásquez Runk 2009). Collaboration facilitates embedding traditional ecological knowledge research within indigenous systems, which as Allen (2009) notes, tend to view people, animals, plants, and other elements of the universe as interconnected by a network of social relationships and obligations.

In these three research projects, this engaged approach to indigenous knowledge via collaboration built trust, which strengthened work and allowed me entrée to a broader landscape of everyday life. For example, I was invited to village leadership meetings, governmental training and meetings, village delegations to sponsored events, distant tourism activities, art sales, and other activities and events outside villages that allowed me to participate in Wounaan's expansive, heterogeneous social landscape. This trust also could create some humorous moments. For example, in the cultural and political ecology work, leaders and I both discussed the ban on medicinal plant study with assistant researchers. However, one member of his village's ecological team often would identify a tree in Spanish and Wounaan meu, and then list and describe all its uses, including medicinal ones. At those times, I spoke aloud, repeating "I am not taking any notes, I am not writing." However, Wounaan enjoyed the scene, and it was repeated frequently enough to be both an expectation and something of an internal joke. This perhaps illustrates the flip side of Lyver et al.'s (2009) comments that work on traditional ecological knowledge may be curtailed by a community's lack of trust of researchers.

A critical, and often unaddressed, aspect of trust in both collaborative and indigenous knowledge research is the decolonization process. When I initially began work with Emberá and Wounaan, both groups were in what I now think of as the early stages of decolonization: although they questioned projects and research, typically there was acceptance of outsiders' interest. Now both Emberá and Wounaan are more vocal actors and assertive in questioning insiders' and outsiders' interests. This is a positive change, but when it rubs up against the traditional norm of conflict avoidance, it may result in misunderstandings. Wounaan still favor their egalitarian traditions, but decolonization can throw into relief some of the tensions between the relatively new hierarchical leadership system and traditions of working in kin groups.

Likewise, my position also has changed over the years. As alluded to above, my own disciplinary boundary crossing from ecology to anthropology, allowed exploration of multiple knowledges and increased collaborative practices, similar to Laborde's (2013) environmental collaboration. Additionally, I moved from a conservation and development practitioner, to graduate student, to faculty member. Although I see myself as nearly the same, I hold more prestige because of my degree and job and attract more suspicion as someone with (in theory) power. I was directly asked to use that power in 2012 after the theft of rosewood trees on the untitled collective lands of two Wounaan communities. Leaders asked me to assess the effect of the rosewood theft on Wounaan livelihoods, and they subsequently used that information with environmental agency officials and the press. In general, I have adapted to my purported power by consciously being more generous with my time, knowledge, and funds. Although I long had considered the redistribution of knowledge in research and committed my time to it, I realized about $15 \mathrm{yr}$ ago that I had not been as generous in terms of my own monies. I now spend personal funds to buy colleagues books on topics of interest, be certain that Wounaan villagers can participate in national meetings, support undergraduate education, ensure people are paid when funds are tied up administratively, or provide food and transportation to facilitate participation and expand social networks via meetings and conferences. (Yet, this can work against me when outsiders or insiders are not as forthcoming.) As Lassiter (2012) has noted, collaboration requires constant moral, ethical, and political negotiation.

This greater recognition of power differentials coupled with length of time working with Wounaan have allowed me to incorporate indigenous methodologies into research. I often work in a junta, in a work party, embracing a more egalitarian approach. Doing so also reinforces a cultural norm of humility. Beyond research colleagues, I take care to tell all Wounaan what I am up to, whether they are leaders or not. I try to take more time for research, to do it, as a Woun who worked with me said, "with calm." Much like the requisite repetition of Wounaan oral traditions, I have learned to repeatedly bring up topics that require extensive consultation, not counting on their adequate discussion the first time they are brought up. Because many Wounaan are reticent to voice concerns in public, I take pains to meet 
individually with people for their opinion. For sensitive topics, I meet with our Wounaan team in private (without other North American colleagues) and then follow up with each individual separately. Collaboration, as Joanne Rappaport (2008: 23) has mentioned, is not for everyone. "It demands," she noted, "a level of commitment to long-term dialogue that is not possible for all scholars, a degree of trust that comes from years of working in the same place, and, most important, a group of interlocutors who can take the lead in cotheorizing." The use of hybrid methodologies facilitates such cotheorizing, allowing us to discuss more intricate or sensitive topics.

Finally, one critically important aspect of collaborative research in indigenous knowledge is coauthorship and the inclusion of multiple voices. Such collaborative writing is time consuming and, ultimately, expensive. With the prominence of publications such as Clifford and Marcus' (1986) Writing Culture and Bretell's (1993) When They Read What We Write, anthropologists take for granted the need to include multiple authors in writing. In spite of that, the academy is not as open to coauthorship as it purports to be. Journal editors and senior professors have chastised my coauthorship of articles with indigenous colleagues, and encouraged me to adopt sole-authored manuscripts even while praising the collaboration. Here, there is an inherent, but unspoken, relationship with power. I have wondered if there might be greater acceptance of crosscultural coauthorship, collaboration, and knowledge if my indigenous colleagues worked in a lab down the hall or also held doctorates.

\section{CONCLUSIONS}

In this paper, I have illustrated how codesigning, coanalyzing, and coauthoring research over years in eastern Panama allowed me to experience different aspects of indigenous life and knowledge. Collaboration has clearly enhanced my scholarship; moreover, it builds an ethos of "standing with" (Tallbear 2014), of networked conversation, engagement, and scholarship. As such, the conceptualization of indigenous knowledge as situated and practiced and the use of a collaborative methodologies are mutually reinforcing. I concur with other researchers that collaboration thus bears potential for revitalizing anthropological thought (Lassiter 2005, Hale 2007, Rappaport 2008, Breunlin and Regis 2009, Laborde 2013).

Recasting this work as indigenous knowledge research held the potential to essentialize results, extracting them from their fluid political, cultural, and historic contexts, yet was done to illuminate the ways that collaborative research can provide new insights to bodies of knowledge. In doing so, however, I magnified my voice, causing my own discomfort, but facilitating my reflection on the decolonizing goals of the collaborative process in indigenous knowledge research. In the original call for papers upon which this feature is based, organizers Mark Mortiz and Matt Laurer similarly implied a need to move beyond an essentialized construction of indigenous knowledge to one based on a more processual foundations.

Responses to this article can be read online at: http://www.ecologyandsociety.org/issues/responses. $\mathrm{php} / 6773$

\section{Acknowledgments:}

I am grateful to numerous leaders, colleagues, and friends for their involvement in and backing of the research on which this article is based. I am especially thankful for the support of the local, regional, and national Wounaan leadership of the Congreso Nacional del Pueblo Wounaan and the Fundación para el Desarrollo del Pueblo Wounaan, as well as the Congreso General de Tierras Colectivas Emberá - Wounaan and the Congreso General Emberá - Wounaan. Wounaan communities in Majé, Puerto Lara, and Panama City have graciously hosted and fortified me over the years. I am indebted to the wonderful friends, colleagues, and collaborators with whom Ihave worked, especially Sergio Achito Mecha, Ron Binder, Chenier Carpio Opua, Doris Cheucarama Membache, Ballarino Cheucarama Membora, Francisco Cheucarama Conquista, Yani Cheucarama Chiripua, James Dalling, José Deago, Wilio Durán Conquista, Bryan James Gordon, Elizabeth Lapovsky Kennedy, Gelo Mejía Peña, Tonny Membora Peña, Chivio Membora Peña, Pinel Mepaquito Teucama, Mayolo Obispo Donisabe, Gervacio Ortíz Negría, Chindio Peña Ismare, Floriselda Peña Conquista, Freicer Peña Membora, Leonardo Peña Conquista, Toño Peña Conquista, Wilio Quintero Quiróz, and Cristobalino Quiróz Ismare, and the other organizations, scholars, friends, and colleagues, too numerous to name here, from whom I have learned. Two anonymous reviewers, Elizabeth Lapovsky Kennedy and Felice Wyndham, provided helpful edits to the manuscript, and I appreciate Felice's suggestion for the article's subtitle. Special thanks to the funders and supporters of these research projects: the UGA Willson Center for Humanities and the Arts, National Science Foundation grant \#BCS 0966520 and 0966046, UGA Faculty Research Grant, Smithsonian Tropical Research Institute, School for Advanced Research Resident Scholar Program, Yale University Program in Agrarian Studies Reciprocity Grant and John Perry Miller Fund Fellowships, American Association of University Women American Dissertation Fellowship, Cullman Fellowship, Fulbright-Hays Dissertation Fellowship, Smithsonian Institution Predoctoral Fellowship, Yale Center for International and Area Studies Dissertation Research Grant, Society for Economic Botany Schultes Award, Yale Wiliams Fund Grant, Smithsonian Tropical Research Institute Short-term Fellowship, Proyecto Cativales, International Tropical Timber Organization, Autoridad Nacional del Ambiente, and United National Development Program.

\section{LITERATURE CITED}

Agrawal, A. 1995. Dismantling the divide between indigenous and scientific knowledge. Development and Change 26:413-439.

Allen, W., J. M. Ataria, J. M. Apgar, G. Harmswoth, and L. A. Tremblay. 2009. Kia ono te mahi putaiao-doing science in the right spirit. Journal of the Royal Society of New Zealand 39:239241. http://dx.doi.org/10.1080/03014220909510588

Andrae-Marobela, K., H. Okatch, A. Masizana-Katongo, B. N. Ngwenya, and K. N. Monyatsi. 2012. The dialectics of indigenous knowledge: Community views from Botswana. AlterNative: Journal of Indigenous Peoples 8:148-162.

Battiste, M. 2008. Research ethics for protecting indigenous knowledge and heritage: institutional and researcher responsibilities. Pages 471-486 in N. K. Denzin, Y. S. Lincoln, 
and L. T. Smith, editors. Handbook of critical and indigenous methodologies. Sage Publications, Thousand Oaks, California, USA.

Brettell, C. 1996. When they read what we write: the politics of ethnography. Bergin and Garvey, Westport, Connecticut, USA.

Breunlin, R., and H. A. Regis. 2009. Can there be a critical collaborative ethnography?: Creativity and activism in the Seventh Ward, New Orleans. Collaborative Anthropologies 2:115146.

Brooks, T. M., R. A. Mittermeier, C. G. Mittermeier, G. A. B. d. Fonseca, A. B. Rylands, W. R. Konstant, P. Flick, J. Pilgrim, S. Oldfield, G. Magin, and C. Hilton-Taylor. 2002. Habitation loss and extinction in the hotspots of biodiversity. Conservation Biology 16:909-923.

Butler, C. 2004. Researching traditional ecological knowledge for multiple uses. Canadian Journal of Native Education 28:33-48.

Clifford, J., and G. E. Marcus, editors. 1986. Writing culture: the poetics and politics of ethnography. University of California Press, Oakland, California, USA.

Cook, S. R. 2009. The collaborative power struggle. Collaborative Anthropologies 2:109-114.

Cooke, B., and U. Kothari, editors. 2001. Participation: the new tyranny? Zed Books, London, UK.

Cruikshank, J. 1998. The social life of stories: narrative and knowledge in the Yukon Territory. University of Nebraska Press, Lincoln, Nebraska, USA.

Denzin, N. K., and Y. S. Lincoln. 2008. Introduction: critical methodologies and indigenous inquiry. Pages 1-20 in N. K. Denzin, Y. S. Lincoln, and L. T. Smith, editors. Handbook of critical and indigenous methodologies. Sage Publications, Thousand Oaks, California, USA.

Dinerstein, E., D. M. Olson, D. J. Graham, A. L. Webster, S. A. Primm, M. P. Bookbinder, and G. Ledec. 1995. Conservation assessment of the terrestrial ecoregions of Latin America and the Caribbean. The World Bank, Washington, D.C., USA.

Dirección de Estadística y Censo. 2012. Censos Nacionales de Población y Vivienda: Tomo 3. Contraloría General de la República, Panamá.

Dove, M. R. 2006. Indigenous peoples and environmental politics. Annual Review of Anthropology 35:191-208.

Echeverri, J. A., and O. E. Román-Jitdutjaaño. 2013. Ash salts and bodily affects: Witoto environmental knowledge as sexual education. Environmental Research Letters 8:1-13. http://dx.doi. org/10.1088/1748-9326/8/1/015034

Ellen, R., P. Parkes, and A. Bicker, editors. 2000. Indigenous environmental knowledge and its transformations: critical anthropological perspectives. Harwood Academic Publishers, Amsterdam, The Netherlands.

Field, L. W. 2008. Abalone tales: collaborative explorations of sovreignty and identity in native California. Duke University Press, Durham, North Carolina, USA. http://dx.doi.org/10.1215/9780$\underline{822391159}$
Field, L., and R. G. Fox, editors. 2007. Anthropology put to work. Berg, New York, New York, USA.

Gallup-Díaz, I. 2001. "Haven't we come to kill the Spaniards?" The Tule upheaval in eastern Panama, 1727-1728. Colonial Latin American Review 10:251-271.

Gow, D. D. 2008. Countering development: indigenous modernity and the moral imagination. Duke University Press, Durham, North Carolina, USA.http://dx.doi.org/10.1215/9780822388807

Hale, C. R. 2007. In praise of "reckless minds:" making a case for activist anthropology. Pages 103-127 in L. Field and R. G. Fox, editors. Anthropology put to work. Berg, New York, New york, USA.

Herlihy, P. H. 1986. A cultural geography of the Embera and Wounaan (Choco) Indians of Darien, Panama, with emphasis on recent village formation and economic diversification. Dissertation, Louisiana State University, Baton Rouge, Louisiana, USA.

Johnson, L. M., and E. S. Hunn. 2010. Landscape ethnoecology: concepts of biotic and physical space. Berghahn Books, New York, New York, USA.

Jones, A., and K. Jenkins. 2008. Rethinking collaboration: working the indigene-colonizer hyphen. Pages 471-486 in N. K. Denzin, Y. S. Lincoln, and L. T. Smith, editors. Handbook of critical and indigenous methodologies. Sage Publications, Thousand Oaks, California, USA.

Laborde, S. 2013. A research practice like Escher's drawing hands: reflections on crossing disciplinary boundaries on Lake Como, Italy. Collaborative Anthropologies 6:290-306.

Laird, S. A., and F. Noejovich. 2002. Building equitable research relationships with indigenous peoples and local communities: prior informed consent and research agreements. Pages 179-220 in $\mathrm{S}$. A. Laird, editor. Biodiversity and traditional knowledge: equitable partnerships in practice. Earthscan, London, UK.

Lassiter, L. E. 2005. The Chicago guide to collaborative ethnography. University of Chicago Press, Chicago, Illinois, USA.

Li, T. 2000. Locating indigenous environmental knowledge in Indonesia. Pages 121-149 in R. Ellen, P. Parkes, and A. Bicker, editors. Indigenous environmental knowledge and its transformations: critical anthropological perspectives. Harwood Academic Publishers, Amsterdam, The Netherlands.

Lowe, B. J., D. J. Carr, R. E. McCallum, T. Myers, A. Gorham, H. Holmes, C. Holtham, L. Matenga, L. Miller, R. NgarimuCameron, W. Raumati, and K. Te Kanawa. 2009. Consultation, collaboration and dissemination. Journal of the Royal Society of New Zealand 39:225-228. http://dx.doi.org/10.1080/03014220909510585

Lyver, P. O. B., C. Jones, and H. Miller. 2009. Looking past the wallpaper: considerate evaluation of traditional environmental knowledge in the sciences. Journal of the Royal Society of New Zealand 39:219-223. http://dx.doi.org/10.1080/03014220909510584

McGinty, S. 2012. Engaging indigenous knowledge(s) in research and practice. GEMA Online Journal of Language Studies 12:5-15.

Mullins, P. R. 2011. Practicing anthropology and the politics of engagement. American Anthropologist 113:235-245. 
Nadasdy, P. 1999. The politics of integration and the "integration" of knowledge. Arctic Anthropology 36:1-18.

Nazarea, V. D., editor. 1999. Ethnoecology: situated knowledgel located lives. University of Arizona Press, Tucson, Arizona, USA.

Rappaport, J. 2005. Intercultural utopias: public intellectuals, cultural experimentation, and ethnic pluralism in Colombia. Duke University Press, Durham, North Carolina, USA. http://dx.doi. org/10.1215/9780822387435

Rappaport, J. 2008. Beyond participant observation: collaborative ethnography as theoretical innovation. Collaborative Anthropologies 1:1-31. http://dx.doi.org/10.1353/cla.0.0014

Shackeroff, J. A., and L. M. Campbell. 2007. Traditional ecological knowledge in conservation research: problems and prospects for their constructive engagement. Conservation and Society 5:343-360.

Sillitoe, P., A. Bicker, and J. Pottier, editors. 2002. Participating in development: approaches to indigenous knowledge. Routledge, London, UK.

Smith, L. T. 2002. Decolozing methodologies: research and indigenous peoples. Zed Books, London, UK.

Stepp, J. R., F. S. Wyndham, and R. Zarger, editors. 2002. Ethnobiology and biocultural diversity: proceedings of the Seventh International Congress of Ethnobiology. University of Georgia Press, Athens, Georgia, USA.

Tallbear, K. 2014. Standing with and speaking as faith: a feministindigenous approach to inquiry. Journal of Research Practice 10 (2): N17. [online] URL: http://jrp.icaap.org/index.php/jrp/article/ view/405/371.

Thomas, W. H. 2009. The forest stewards initiative: a new institution for safeguarding ecological knowledge in Papua New Guinea. Journal of the Royal Society of New Zealand 29:187-191. http://dx.doi.org/10.1080/03014220909510577

Velásquez Runk, J. 2001. Wounaan and Emberá use and management of the fiber palm Astrocaryum standleyanum (Arecaceae) for basketry in eastern Panamá. Economic Botany $55: 72-82$.

Velásquez Runk, J. 2009. Social and river networks for the trees: Wounaan's riverine rhizomic cosmos and arboreal conservation. American Anthropologist 111:456-467. http://dx.doi.org/10.1111/ j.1548-1433.2009.01155.x

Velásquez Runk, J., G. Ortíz Negría, L. Peña Conquista, G. Mejía Peña, F. Peña Cheucarama, and Y. Cheucara Chiripua. 2010. Landscapes, legibility, and conservation planning: multiple representations of forest use in Panama. Conservation Letters 3:167-176.

Velásquez Runk, J., G. Ortíz Negría, W. Quintero García, and C. Quiróz Ismare. 2007. Political economic history, culture, and Wounaan livelihood diversity in eastern Panama. Agriculture and Human Values 24:93-106.
Velásquez Runk, J., F. Peña, and P. Mepaquito. 2004. Artisanal non-timber forest products in Darién Province, Panamá: the importance of context. Conservation and Society 2:217-234.

West, P. 2006. Conservation is our government now: the politics of ecology in Papua New Guinea. Duke University Press, Durham, North Carolina, USA.http://dx.doi.org/10.1215/9780822388067

Wohling, M. 2009. The problem of scale in indigenous knowledge: a perspective from northern Australia. Ecology and Society 14(1): 1. [online] URL: http://www.ecologyandsociety.org/vol14/iss1/ art1/.

Yarrow, T. 2008. Negotiating difference: discourses of indigenous knowledge and development in Ghana. Political and Legal Anthropology Review 31:224-242.

Zent, S. 2009. A geneaology of scientific representations of indigenous knowledge. Pages 19-67 in S. Heckler, editor. Landscape, process, and power: re-evaluating traditional environmental knowledge. Berghahn Books, New York, New York, USA. 